\title{
ESTIMASI BIAYA KONSTRUKSI GEDUNG DENGAN COST SIGNIFICANT MODEL
}

\author{
I Nyoman Yudha Astana \\ Program Studi Teknik Sipil, Universitas Udayana Bukit Jimbaran, Badung, Bali. \\ E-mail : astana_yudha@yahoo.com
}

\begin{abstract}
ABSTRAK
Estimasi biaya proyek sangat diperlukan dalam perencanaan sebuahproyek. Pada tahap awal, estimasi biaya digunakan untuk mengetahui berapabesar biaya yang dibutuhkan untuk mewujudkan suatu proyek. Denganketerbatasan waktu dan informasi maka Cost Significant Model merupakan metode estimasi yang mudahdan efektif untuk memberikan gambaran awal biaya proyek.Penelitian ini bertujuan untuk mendapatkan suatu model estimasi biayakonstruksi gedung pemerintah di Kabupaten Jembrana, Provinsi Bali, dengan mengambil data sekunder dari lima belas proyek gedungpemerintah. Prinsip yang digunakan untuk mendapatkanmodel biaya adalah identifikasi cost significant item yang berpengaruh terhadaptotal biaya pekerjaan, kemudian dianalisis untuk menghasilkan rumusanpersamaan regresi.Hasil penelitian menunjukkan bahwa komponen pekerjaan yang secarasignifikan mempengaruhi biaya konstruksi gedung pemerintah di KabupatenJembrana adalah biaya pekerjaan beton, biaya pekerjaan kap/atap, biayapekerjaan finishing/style Bali, dan biaya pekerjaan pintu \& jendela. Model estimasi dinyatakan dalam persamaan $\mathrm{Y}=510,481+0,888 \mathrm{X}_{5}+1,385 \mathrm{X}_{6}+1,328 \mathrm{X}_{12}+1,726 \mathrm{X}_{8}$, dimana $\mathrm{Y}=$ Biaya pembangunan gedung $\left(\mathrm{Rp} / \mathrm{m}^{2}\right), \mathrm{X}_{5}=$ Biaya pekerjaan beton $\left(\mathrm{Rp} / \mathrm{m}^{2}\right), \mathrm{X}_{6}=$ Biaya pekerjaan $\mathrm{kap}\left(\mathrm{Rp} / \mathrm{m}^{2}\right)$, $\mathrm{X}_{12}=$ Biaya pekerjaan finishing/style Bali $\left(\mathrm{Rp} / \mathrm{m}^{2}\right)$, dan $\mathrm{X}_{8}=$ Biaya pekerjaan pintu dan jendela $\left(\mathrm{Rp} / \mathrm{m}^{2}\right)$. Penyimpangan model biaya konstruksi gedung dengan cost significantmodel adalah rata-rata $1,81 \%$ untuk yang bernilai positif dan $2,06 \%$ untuk yangbernilai negatif.
\end{abstract}

Kata kunci : Estimasi Biaya, Cost Significant Model, Konstruksi Gedung

\begin{abstract}
The estimated cost of the project is necessary in project planning. At the early stage, cost estimates used to determine how much it cost to realize a project. With limited time and information, the Significant Cost Model is an easy and effective method, to provide an overview of the initial of the project cost. This study aims to obtain a model of construction cost estimates of buildings in Jembrana, Bali Province, by taking fifteen secondary data from government projects. The principle used to obtain a cost model is the identification of significant cost items that affect the total cost of the work, and then analyzed to produce a regression equation formulation. The results showed that the component significantly affects the cost of construction in Jembrana is the cost of concrete work, the cost of the roof structure/roof, cost of finishing work/Balinese style, and the cost of doors \& windows. The Model estimates expressed in the equation $Y=510,481+0,888 X_{5}+1,385 X_{6}+1,328 X_{12}+1,726 X_{8}$, where $Y=$ Cost of construction $(R p / m 2), X_{5}=$ cost of concrete work $(R p / m 2), X_{6}=$ cost of roof structure/roof (Rp/m2), $X_{12}=$ cost of finishing work/Balinese style $(R p / m 2)$, and $X_{8}=$ cost of doors and windows ( Rp/m2). Deviation of construction cost model with significant cost models is an average of $1.81 \%$ for positive value and $2.06 \%$ of negative.
\end{abstract}

Keywords : Cost Estimation, Cost Sgnificant Models, Building Construction

\section{PENDAHULUAN}

Dalam pelaksanaanproyek konstruksi dibutuhkan beberapa macam estimasi yang, didasarkan atas tujuan penggunaan dan peruntukannya. Pada tahap awal perencanaan proyek gedung, seperti pada saat penyusunan anggaran proyek, estimasi tidak mungkin didasarkan pada perhitungan kuantitas (volume) pekerjaan karena uraian dan spesifikasi pekerjaan belum tersusun. Akan tetapi, pemilik proyek (owner) memerlukan estimasi biaya dalam rangka menyusun anggaran proyek. Seiring dengan kebutuhan akan efisiensi, perlu dikembangkan teknik pembuatan 
model estimasi biaya, yang sederhana, cepat, mudah dalam penggunaannya, akurat dan menghasilkan estimasi yang dapat dipertanggungjawabkan. Metode Cost Significant Model diharapkan dapat memberi jawaban terhadap tuntutan akan tersedianya estimasi biaya awal proyek.

\section{Tujuan penelitian}

Tujuan penelitian ini adalah, mengembangkan suatu model estimasi yang dapat memberikan informasi biaya awal proyek secara cepat, mudah dan dengan hasil yang cukup akurat.

\section{Tinjauan Pustaka}

Menurut Soeharto [1], estimasi biaya proyek memegang peranan penting dalam penyelenggaraan proyek. Pada tahap awal estimasi biaya dipergunakan untuk mengetahui berapa besar biaya yang dibutuhkan untuk membangun suatu proyek.Menurut National Estimating Society - USA, Perkiraan biaya adalah seni memperkirakan (the art of approximating) kemungkinan jumlah biaya yang diperlukan untuk suatu kegiatan yang didasarkan atas informasi yang tersedia pada saat itu.Kegiatan estimasi adalah suatu proses utama dalam proyek konstruksi untuk menjawab pertanyaan berapa besar dana yang harus disediakan untuk sebuah bangunan [2]. Estimasi biaya proyek dapat dikelompokkan secara berurutan, sebagai berikut [3].

1. Estimasi pendahuluan, dibuat pada tahap awal proyek.

2. Estimasi terperinci, dibuat dengan dasar hitungan volume pekerjaan, biaya, serta harga satuan pekerjaan.

3. Estimasi definitif, merupakan gambaran pembiayaan dan pertanggungjawaban rampung untuk suatu proyek dengan hanya kemungkinan kecil terjadi kesalahan.

\section{Dasar-Dasar dan langkah Cost Significant Model}

Menurut Poh dan Horner [4]Cost Significant Model mengandalkan pada penemuan yang terdokumentasi dengan baik, bahwa $80 \%$ dari nilai total biaya proyektermuat di dalamnya $20 \%$ item-item pekerjaan yang paling mahal. Untuk proyek yang memiliki ciri-ciri yang sejenis, item-item cost significant secara umum adalah sama. Cost significant items dapat dikumpulkan dengan menggunakan teknik yang bervariasi ke dalam nomor yang sama dari item-item pekerjaan cost-significant, yang dapat mempresentasikan proporsi yang tepat dari total biaya anggaran yang biasanya mendekati $80 \%$. Penyederhanaan dari model ini mengurangi waktu untuk mengestimasi biaya dibandingkan dengan anggaran biaya tradisional, yang dapat terdiri dari ribuan item. Cost significant modeldapat digunakan untuk mengestimasi biaya lebih baik. dan akurasi dapat ditingkatkan dengan memperbaiki model serta tergantung dari data yang tersedia [5].

Metode Cost Significant Model yang digunakan didasarkan pada analisa data proyek yang lalu, dengan langkahlangkah sebagai berikut :

1. Tidak mengikutsertakan item pekerjaan yang kadang-kadang jumlahnya cukup besar namun tidak setiap pekerjaan ada.

2. Mengelompokkan item-item pekerjaan yang mempunyai satuan ukuran yang sama, harga satuannya tidak berbeda secara signifikan, atau bisa menggambarkan operasi kerja lapangan.

3. Menghitung pengaruh time value terhadap harga-harga item pekerjaan dengan memperhitungkan faktor inflasi.

4. Mencari cost significant items, yang diidentifikasi sebagai item-item terbesar yang jumlah prosentasenya sama atau lebih besar dari $80 \%$ total biaya proyek.

5. Membuat model biaya dari cost significant items yang telah ditentukan.

6. Mencari rata-rata Cost Model Faktor (CMF) dengan cara membagi nilai proyek yang didapatkan dari model dengan nilai aktual proyek.

7. Menghitung estimasi biaya proyek dari Cost Significant Model, dengan membagi nilai proyek yang diprediksi dari model dengan rata-rata CMF.

8. Menghitung akurasi model dalam bentuk prosentase dari selisih antara harga yang diprediksi dengan harga sebenarnya dibagi dengan harga sebenarnya.

$$
\begin{aligned}
& \text { Akurasi }=\left(\frac{E v-A v}{\Delta v}\right) \times 100 \% \\
& \text { Dimana : } \\
& \text { Ev }=\text { harga prediksi (Estimated bill value) } \\
& \text { Av }=\text { harga sebenarnya (Actual bill value) }
\end{aligned}
$$




\section{Komponen Utama Biaya Konstruksi}

Dalam pekerjaan proyek konstruksi biaya total proyek merupakan jumlah komponen biaya yang meliputi: biaya material, biaya tenaga kerja, biaya peralatan, biaya tak langsung, dan keuntungan sebagai berikut[3].

1. Biaya material, meliputi perhitungan seluruh kebutuhan volume dan biaya material yang digunakan untuk setiap komponen bangunan, baik material pekerjaan pokok maupun penunjang.

2. Biaya Tenaga Kerja. merupakan aspek yang paling sulit dari keseluruhan analisis biaya konstruksi. Banyak sekali faktor berpengaruh yang yang harus diperhitungkan.

3. Biaya Peralatan. termasuk pembelian atau sewa, mobilisasi, demobilisasi, memindahkan,transportasi, pemasangan, pembongkaran, dan pengoperasian selama konstruksi berlangsung.

4. Biaya Tidak Langsung, dibagi dua golongan, biaya umum atau overhead cost dan biaya proyek. Yang dikelompokkan sebagai biaya umum adalah: (1) gaji personil tetap kantor pusat dan lapangan; (2) pengeluaran kantor pusat seperti sewa kantor, telepon, dan sebagainya; (3)perjalanan beserta akomodasi; (4) biaya dokumentasi; (5) bunga bank; (6)biaya notaris; (7) peralatan kecil dan habis pakai. Sedangkan yang dapat dikelompokkan sebagai biaya proyek, pengeluarannya dapat dibebankan pada proyek tetapi tidak dimasukkan pada biaya material, upah kerja, atau peralatan, yaitu: (1) bangunan kantor lapangan beserta perlengkapannya; (2) biaya telepon kantor lapangan; (3) kebutuhan akomodasi lapangan seperti listrik, air bersih, air minum, sanitasi, dan sebagainya; (4) jalan kerja dan parkir, batas perlindungan dan pagar di lapangan; (5) pengukuran lapangan; (6) tanda - tanda untuk pekerjaan dan kebersihan lapangan pada umumnya; (7) pelayanan keamanan dan keselamatan kerja; (8) pajakpertambahan nilai; (9) biaya asuransi; (10) jaminan penawaran, jaminanpelaksanaan dan jaminan pemeliharaan; (11) asuransi risiko pembangunandan asuransi kerugian; (12) surat ijin dan lisensi; (13) inspeksi, pengujian,dan pengetesan; (14) sewa peralatan besar utama; dan (15) premi pekerjabila diperlukan.

5. Keuntungan, umumnya dinyatakansebagai persentase dari seluruh jumlah pembiayaan. Secara umum,biasanya untuk proyek kecil ditetapkan prosentase yang semakin besar,demikian pula sebaliknya. Pada prinsipnya penetapanbesarnya keuntungan juga dipengaruhi oleh besarnya resiko atau kesulitan-kesulitan yang akan dihadapi yang seringkali tidak tampak nyata.

\section{METODE PENELITIAN}

Teknik analisis yang digunakan dalam penelitian ini adalahanalisis statistik deskriptif dan analisis infrensial. Analisis statistik deskriptifadalah statistik yang digunakan untuk menganalisa data dengan caramendeskripsikan data yang telah terkumpul tanpa bermaksud membuat kesimpulan yang berlaku secara umum ataugeneralisasi. sehingga jenis analisis ini bersifat mendukung analisis selanjutnya. Analisa statistik infrensial meliputi analisis regresi berganda yangdipergunakan untuk mengetahui model estimasi biaya total proyek. Metode regresiberganda ini menggunakan asumsi bahwa biaya total konstruksi sebagai variabelterikat dan item-item biaya signifikan sebagai variabel bebas.Untuk dapat melaksanakan tahapan teknik analisis data, pada tahap awal datadikelompokan berdasarkan variabel-variabel tersebut di atas. Data yang dianalisis merupakan data yang sudah dikelompokkan, dan didalam analisis tidak melibatkan biaya-biaya pekerjaan diluar gedung. Setelah datadikelompokkan, tahap selanjutnya adalah sebagai berikut:

\section{Perhitungan Pengaruh Time Value}

Apabila tahun anggaran pelaksanaan proyek tidak sama, maka semua biaya-biayaperlu dilakukan perhitunganpengaruh time value[7].

$F=P(1+f)^{n}$

dimana:

$\mathrm{P}=$ harga pada tahun pelaksanaan

$\mathrm{F}=$ nilai harga pada tahun yang ditentukan

$\mathrm{f}=$ faktor inflasi

$\mathrm{n}=$ tahun

\section{Identifikasi Cost Significant Items}

Dengan mengacu pada prinsip dasar Pareto costsignifican model mengandalkan pada 80 persen dari total nilaiproyek yang termuat didalam 20 persen item-item pekerjaan yangpaling mahal. Untuk menentukan item 
pekerjaan yang signifikan,dilakukan dengan melihat deskripsi hasil penelitian, sehingga diperoleh proporsimasing-masing komponen biaya (variabel bebas) terhadap jumlah biaya(variabel terikat).

3. Uji Persyaratan Analisis

Uji normalitas dilakukan dengan bantuan computer program SPSS (Statistical Product and Service Solution) berdasarkan uji Kolmogorov Smirnov yaitu denganmembandingkan nilai probabilitasnya dengan signifikan levelnya [6].

4. Analisis Data

Analisis menggunakan analisisregresi berganda, dengan bantuan program SPSS, sebagai berikut:

a. Koefisien korelasi (R).

Menganalisis derajat keeratan hubungan (korelasi) antaraantara variabel terikat dengan variabel bebas dan mengetahui arahhubungan antara dua variabel.

b. Koefisien determinasi $\left(\mathrm{R}^{2}\right)$.

Untuk mengetahui besarnya prosentase pengaruh semua variabelindependen terhadap variabel dependen.

d. Uji ANOVA atau F test

Untuk mengetahui pengaruh semua variabel independen (secarasimultan) di dalam model regresi terhadap nilai variabel dependen.

e. Uji t

Untuk mengetahui apakah variabel independen yang terdapatdalam model regresi secara individu berpengeruh terhadap nilaivariabel dependen (uji parsial) caranya adalah dengan melakukanpengujian terhadap koefisien regresi setiap variabel independenatau uji t.

\section{Akurasi Model}

Dapat dilakukan dengan cara membagibiaya estimasi model denganCMF. Akurasi modeldalam bentuk prosentase dari selisih antara harga yang diprediksi denganharga sebenarnya dibagi dengan harga sebenarnya.

\section{HASIL DAN PEMBAHASAN}

Dari analisis yang dilakukan,dapat diketahui proporsi komponen biaya konstruksi gedung adalah: pekerjaan persiapan $\left(\mathrm{X}_{1}\right)$ sebesar $0,58 \%$, pekerjaan tanah $\left(\mathrm{X}_{2}\right)$ sebesar $2,21 \%$,pekerjaan pasangan $\left(\mathrm{X}_{3}\right)$ sebesar 8,65 $\%$,pekerjaan plesteran dan acian $\left(\mathrm{X}_{4}\right)$ sebesar $4,87 \%$,pekerjaan beton $\left(\mathrm{X}_{5}\right)$ sebesar30,44 \%, pekerjaan kap/atap $\left(\mathrm{X}_{6}\right)$ sebesar $14,58 \%$,pekerjaan lantai dan dinding $\left(\mathrm{X}_{7}\right)$ sebesar 6,72 \%,pekerjaan pintu dan jendela $\left(\mathrm{X}_{8}\right)$ sebesar $9,44 \%$, pekerjaan plafond $\left(\mathrm{X}_{9}\right)$ sebesar 8,39\%,pekerjaan sanitasi $\left(\mathrm{X}_{10}\right)$ sebesar 1,64\%, pekerjaan instalasi listrik/ ME $\left(\mathrm{X}_{11}\right)$ sebesar 3,04\%, dan pekerjaan finishing/style Bali $\left(\mathrm{X}_{12}\right)$ sebesar 9,44\%, seperti Tabel 1.

Tabel 1 : Proporsi Harga Item Pekerjaan Konstruksi Gedung di Kabupaten Jembrana (Rp.x1000 per m2)

\begin{tabular}{clrrrr}
\hline No & Item Pekerjaan & Minimum & \multicolumn{1}{c}{ Maximum } & \multicolumn{1}{c}{ Mean } & Prosentase $(\%$ \\
\hline 1 & Pekerjaan Persiapan $\left(\mathrm{X}_{1}\right)$ & $1,108.57$ & $39,867.30$ & $16,571.64$ & $0.58 \%$ \\
2 & Pekerjaan Tanah $\left(\mathrm{X}_{2}\right)$ & $7,948.43$ & $158,762.52$ & $63,367.76$ & $2.21 \%$ \\
3 & Pekerjaan Pasangan $\left(\mathrm{X}_{3}\right)$ & $95,593.73$ & $792,073.10$ & $248,232.98$ & $8.65 \%$ \\
4 & Pekerjaan Plesteran $\left(\mathrm{X}_{4}\right)$ & $29,442.40$ & $266,877.23$ & $139,636.85$ & $4.87 \%$ \\
5 & Pekerjaan Beton $\left(\mathrm{X}_{5}\right)$ & $261,468.43$ & $3,151,758.83$ & $873,552.68$ & $30.44 \%$ \\
6 & Pekerjaan Kap $\left(\mathrm{X}_{6}\right)$ & $102,555.09$ & $1,030,840.48$ & $418,485.38$ & $14.58 \%$ \\
7 & Pekerjaan Dinding \& Lantai $\left(\mathrm{X}_{7}\right)$ & $41,368.85$ & $572,777.72$ & $192,927.68$ & $6.72 \%$ \\
8 & Pekerjaan Pintu \& Jendela $\left(\mathrm{X}_{8}\right)$ & $89,525.93$ & $720,273.09$ & $270,970.76$ & $9.442 \%$ \\
9 & Pekerjaan Plapon $\left(\mathrm{X}_{1} 9\right)$ & $37,560.06$ & $588,716.53$ & $240,920.58$ & $8.39 \%$ \\
10 & Pekerjaan Sanitasi $\left(\mathrm{X}_{10}\right)$ & $12,475.50$ & $93,491.08$ & $47,113.47$ & $1.64 \%$ \\
11 & Pekerjaan M/E $\left(\mathrm{X}_{11}\right)$ & $16,019.78$ & $237,194.42$ & $87,176.41$ & $3.04 \%$
\end{tabular}




\begin{tabular}{|c|c|c|c|c|}
\hline 12 & Pekerjaan Finishing/style Bali $\left(\mathrm{X}_{12}\right)$ & $86,447.78$ & $850,924.93$ & $9.443 \%$ \\
\hline & & & Jumlah & $100 \%$ \\
\hline
\end{tabular}

Sumber : Analisis dengan Excel

Adapun rata-rata proporsi komponen biaya per m2,dari komponen terbesar sampai terkecil, ditampilkan dalam bentuk grafik seperti pada Gambar 1.

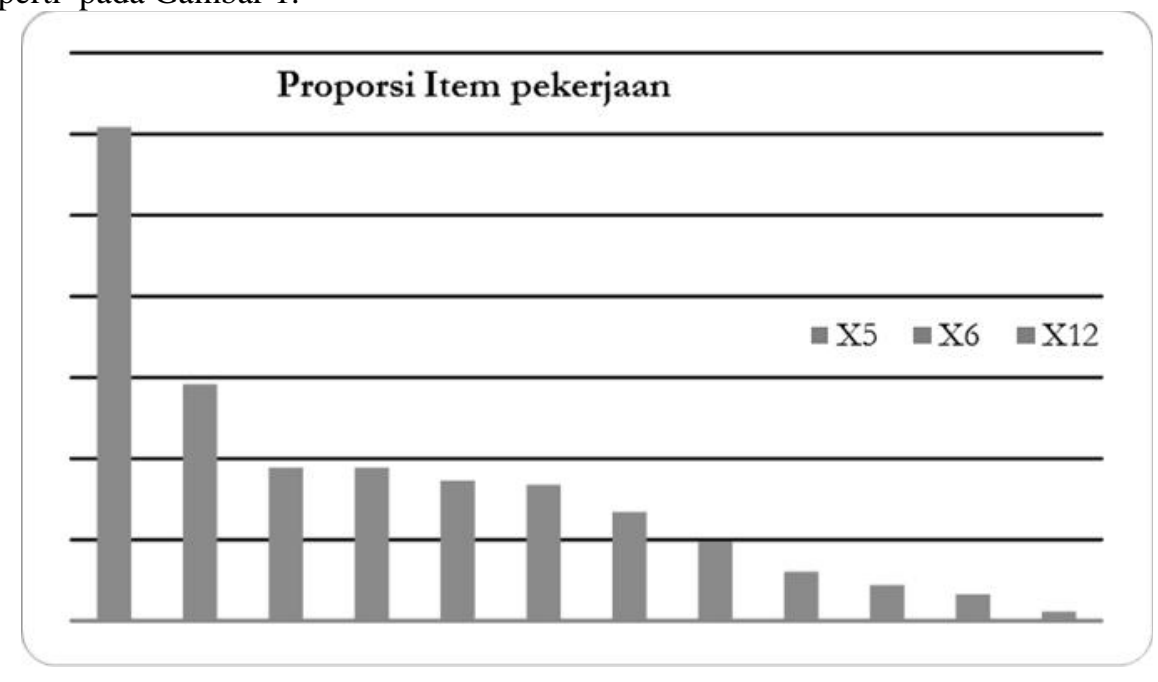

Gambar 1 : Proporsi Item Pekerjaan konstruksi Gedung di Kabupaten Jembrana

Proporsi masing-masing komponen biaya seperti pada Tabel 1. selanjutnya diurut dari yang terbesar sampai terkecil. Cost significant items diidentifikasi sebagai item-item terbesar yang jumlah prosentasenya sama atau lebih besar dari $80 \%$ jumlah biaya.Tabel 2memperlihatkan 6 (enam) cost significant items yang memiliki biaya komulatif $(80,95 \%)$ dari total biaya yaitu : pekerjaan beton (X5), pekerjaan kap/ atap (X6), pekerjaan finishing/style bali (X12), dan pekerjaan pintu dan jendela (X8), pekerjaan pasangan (X3), pekerjaan plafon (X9). Sedangkan Gambar 2 menunjukkan komulatif biaya pekerjaan konstruksi gedung di Kabupaten Jembrana. Variabel bebas yang diidentifikasi sebagai cost significant items inilah yang selanjutnya akan dianalisis dengan menggunakan program SPSS.

Tabel 2 : Cost Significant Item Pekerjaan Konstruksi Gedung di Kabupaten Jembrana

\begin{tabular}{cccc}
\hline No & Item Pek. & Prosentase(\%) & Komulatif (\%) \\
\hline 1 & X5 & $30.44 \%$ & $30.44 \%$ \\
2 & X6 & $14.58 \%$ & $45.02 \%$ \\
3 & X12 & $9.443 \%$ & $54.46 \%$ \\
4 & X8 & $9.442 \%$ & $63.90 \%$ \\
5 & X3 & $8.65 \%$ & $72.55 \%$ \\
6 & X9 & $8.39 \%$ & $80.95 \%$ \\
7 & X7 & $6.72 \%$ & $87.67 \%$ \\
8 & X4 & $4.87 \%$ & $92.54 \%$ \\
9 & X11 & $3.04 \%$ & $95.57 \%$ \\
10 & X2 & $2.21 \%$ & $97.78 \%$ \\
11 & X10 & $1.64 \%$ & $99.42 \%$ \\
12 & X1 & $0.58 \%$ & $100.00 \%$ \\
\hline
\end{tabular}




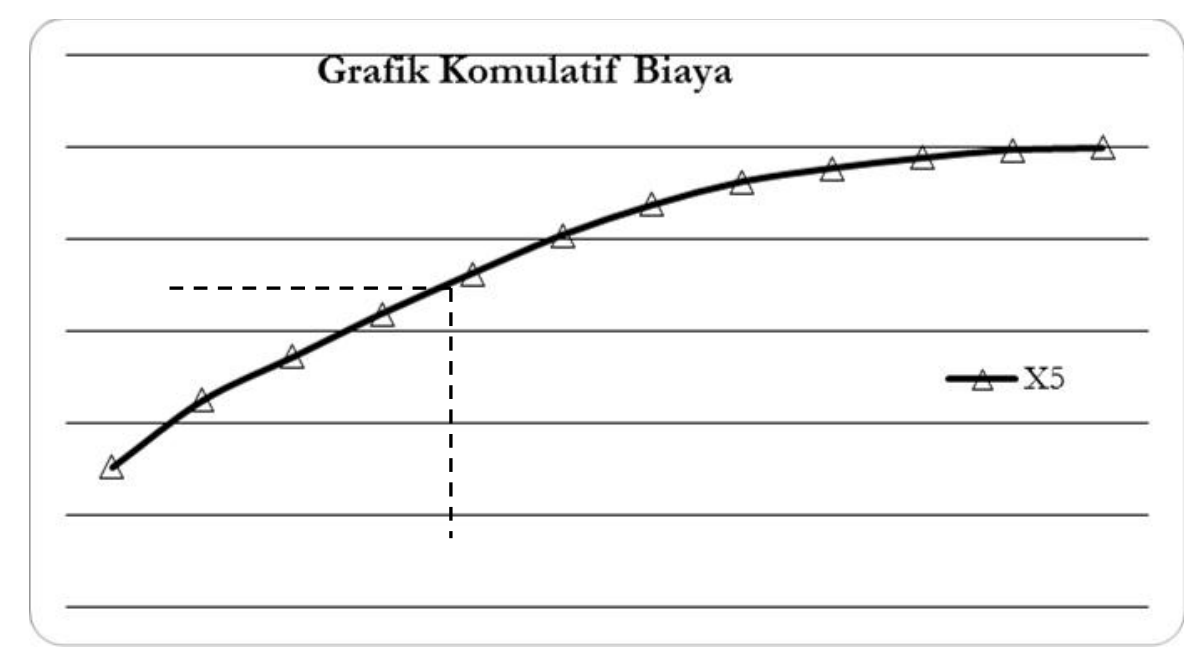

Gambar 2 : Grafik Komulatif Biaya Pekerjaan konstruksi Gedung di Kabupaten Jembrana

Tabel 3 memperlihatkan Uji Normalitas berdasarkan besarnya nilai Kolmogorov-Smirnov adalah 0,409 dan signifikan pada 0,996, hal ini menyatakan Ho diterima yang berarti data residual terdistribusi normal. Atau dapat juga dilihat dari grafik normal plot. Pada Gambar 3, Grafik normal P-P plot terlihat titik menyebar di sekitar garis diagonal. Jika data menyebar di sekitar garis diagonal, maka model regresi memenuhi asumsi normalitas.

Tabel 3 : Uji Kolmogorov-Smirnov

\begin{tabular}{|c|c|c|}
\hline \multicolumn{3}{|c|}{ One-Sample Kolmogorov-Smirnov Test } \\
\hline & $\begin{array}{c}\text { Unstandardized } \\
\text { Residwal }\end{array}$ \\
\hline \multicolumn{2}{|l|}{$\mathrm{N}$} & 15 \\
\hline \multirow{2}{*}{$\begin{array}{l}\text { Normal } \\
\text { Parameters }\end{array}$} & Mean & $0 \mathrm{E}-7$ \\
\hline & Std. & 77.8434130 \\
\hline \multirow{3}{*}{$\begin{array}{l}\text { Most Extreme } \\
\text { Differences }\end{array}$} & Absolute & .106 \\
\hline & Positive & .095 \\
\hline & Negative & -.106 \\
\hline \multicolumn{2}{|c|}{ Kolmogorov-Smirnov Z } & .409 \\
\hline \multicolumn{2}{|c|}{ Asymp. Sig. (2-tailed) } & .996 \\
\hline
\end{tabular}

a. Test distribution is Normal.

b. Calculated from data.

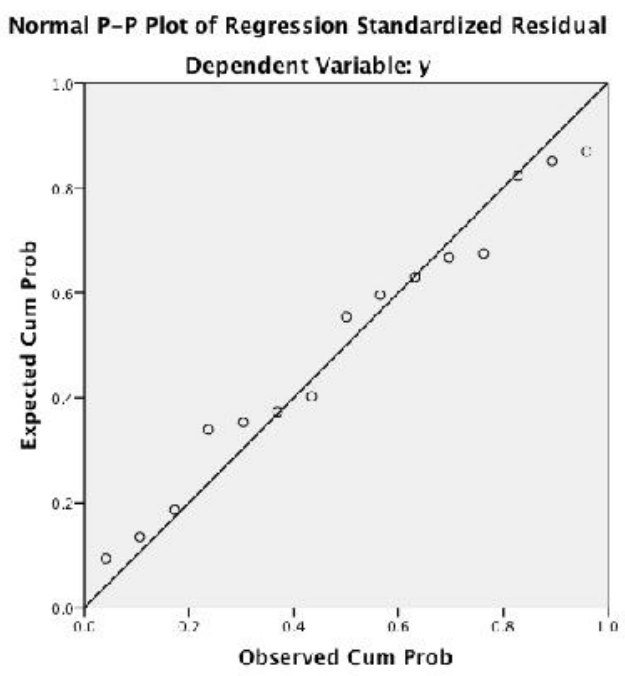

Gambar 3 : Grafik Normal P-P Plot 
Hasil analisis dengan SPSS menunjukkan angka koefisien determinasi $\left(\mathrm{R}^{2}\right)=0,973$ menunjukkan bahwa $97,3 \%$ biaya (Y) dipengaruhi oleh faktor X9, X8, X5, X12, X6 dan X3. Sedangkan sisanya $(100 \%-97,3 \%)=2,7 \%$ dipengaruhi oleh faktor lain.

\begin{tabular}{|c|c|c|c|c|c|}
\hline \multicolumn{6}{|c|}{ Model Summary ${ }^{b}$} \\
\hline Model & $\mathrm{R}$ & R Square & Adjusted R Square & $\begin{array}{l}\text { Std. Error of the } \\
\text { Estimate }\end{array}$ & Durbin-Watson \\
\hline 1 & $.986^{\mathrm{a}}$ & .973 & .952 & 102.97716 & 1.880 \\
\hline \multicolumn{6}{|c|}{ a. Predictors: (Constant), X9, X8, X5, X12, X6, X3 } \\
\hline \multicolumn{6}{|c|}{ b. Dependent Variable: Y } \\
\hline
\end{tabular}

Sedangkan Uji Anova atau uji F, menunjukkan tingkat signifikasi $0,000<0,05$, maka model regresi bisa dipakai untuk memprediksi biaya. Atau bisa dijelaskan bahwa faktor X9, X8, X5, X12, X6 dan X3 berpengaruh terhadap biaya pekerjaan (Y).

\begin{tabular}{llrrrrr}
\hline \multicolumn{5}{c}{ ANOVA $^{\mathrm{a}}$} & & \\
\hline Model & & Sum of Squares & df & Mean Square & F & Sig. \\
& Regression & 3029350.964 & 6 & 504891.827 & 47.612 & $.000^{\mathrm{b}}$ \\
\multirow{2}{*}{1} & Residual & 84834.357 & 8 & 10604.295 & & \\
& Total & 3114185.321 & 14 & & & \\
\hline
\end{tabular}

a. Dependent Variable: Y

b. Predictors: (Constant), X9, X8, X5, X12, X6, X3

Selanjutnya dengan melakukan analisis regresi dari keenam variabel independenyang dimasukkan ke dalam model, diperoleh bahwa variabel $\mathrm{X}_{3}$ dan $\mathrm{X}_{9}$ tidak signifikan. Hal ini dapat dilihat dari probabilitas signifikansi untuk $\mathrm{X}_{3}$ sebesar 0,372, dan $\mathrm{X}_{9}$ sebesar 0,448, sehingga jauh diatas 0,05. Sedangkan nilai signifikansi $\mathrm{X}_{5}=0,000<0,05, \mathrm{X}_{6}=$ $0,001<0,05, X_{12}=0,002<0,05$ dan $X_{8}=0,007<0,05$. Dapat disimpulkan bahwa biaya proyek dipengaruhi oleh $X_{5}, X_{6}$, $\mathrm{X}_{12}$, dan $\mathrm{X}_{8}$, dengan persamaan regresi $\mathrm{Y}=510,481+0,888 \mathrm{X}_{5}+1,385 \mathrm{X}_{6}+1,328 \mathrm{X}_{12}+1,726 \mathrm{X}_{8}$. Dimana $\mathrm{Y}=$ Biaya pembangunan gedung $\left(\mathrm{Rp} / \mathrm{m}^{2}\right), \mathrm{X}_{5}=$ Biaya pekerjaan beton $\left(\mathrm{Rp} / \mathrm{m}^{2}\right), \mathrm{X}_{6}=$ Biaya pekerjaan $\mathrm{kap}\left(\mathrm{Rp} / \mathrm{m}^{2}\right), \mathrm{X}_{12}=\mathrm{Biaya}$ pekerjaan finishing/style Bali $\left(\mathrm{Rp} / \mathrm{m}^{2}\right), \mathrm{X}_{8}=$ Biaya pekerjaan pintu dan jendela $\left(\mathrm{Rp} / \mathrm{m}^{2}\right)$.

Konstanta 510,481 menyatakan bahwa jika variabel independen dianggap konstan, maka biaya per

meter persegi biaya pembangunan gedung pemerintah

adalah sebesar Rp. 510,481. Koefisien regresi 0,888 menyatakan bahwa setiap penambahan satu satuan harga pekerjaan beton, maka akan meningkatkan biaya per meter persegi pembangunan gedung pemerintah sebesar 0,888 . Koefisien regresi 1,385 menyatakan bahwa setiap penambahan satu satuan harga pekerjaan kap, maka akan meningkatkan biaya per meter persegi pembangunan gedung pemerintah sebesar 1,385.Koefisien regresi 1,328 menyatakan bahwa setiap penambahan satu satuan harga pekerjaan finishing, maka akan meningkatkan biaya per meter persegi pembangunan gedung pemerintah sebesar 1,328.Koefisien regresi 1,726 menyatakan bahwa setiap penambahan satu satuan harga pekerjaan pintu dan jendela, maka akan meningkatkan biaya per meter persegi pembangunan gedungpemerintah sebesar 1,726.

\begin{tabular}{|c|c|c|c|c|c|c|c|c|}
\hline \multicolumn{9}{|c|}{ Coefficients $^{\mathrm{a}}$} \\
\hline & \multirow[t]{2}{*}{ Model } & \multicolumn{2}{|c|}{ Unstandardized } & \multirow{2}{*}{$\begin{array}{c}\text { Standardized } \\
\text { Beta }\end{array}$} & \multirow[t]{2}{*}{$\mathrm{t}$} & \multirow[t]{2}{*}{ Sig. } & \multicolumn{2}{|c|}{ Collinearity Statistics } \\
\hline & & $\mathrm{B}$ & Std. Error & & & & Tolerance & VIF \\
\hline \multirow{2}{*}{1} & (Constant) & 510.481 & 334.463 & & 1.526 & .165 & & \\
\hline & X5 & .888 & .129 & .551 & 6.876 & .000 & .530 & 1.887 \\
\hline
\end{tabular}




\begin{tabular}{lrrrrrrr} 
X6 & 1.385 & .274 & .574 & 5.059 & .001 & .265 & 3.779 \\
$\mathrm{X} 12$ & 1.328 & .291 & .374 & 4.568 & .002 & .508 & 1.970 \\
$\mathrm{X} 8$ & 1.726 & .475 & .313 & 3.637 & .007 & .458 & 2.181 \\
$\mathrm{X} 3$ & .660 & .698 & .121 & .946 & .372 & .210 & 4.766 \\
$\mathrm{X} 9$ & .533 & .667 & .124 & .798 & .448 & .142 & 7.055 \\
\hline
\end{tabular}

a. Dependent Variable: Y

Model regresi $\mathrm{Y}=510,481+0,888 \mathrm{X}_{5}+1,385 \mathrm{X}_{6}+1,328 \mathrm{X}_{12}+1,726 \mathrm{X}_{8}$, yang telah didapat, perlu dilakukan pengujian terhadap penyimpangannya. Menurut Poh dan Horner [4],pengujian terhadap penyimpangan model dapat dilakukan dengan cara membagi jumlah nilai proyek yang telah diprediksi, dengan nilaiCost Model Factor(CMF).Sedangkan CMF merupakan rasio dari total biaya yang diestimasi berdasarkan model yang telah didapat, dengan total biaya proyek sebenarnya, seperti ditunjukkan Tabel 4.

Tabel 4Cost Model Factor

\begin{tabular}{cccc}
\hline No & $\begin{array}{c}\text { Harga Penawaran } \\
\text { per m2 luas lantai }\end{array}$ & $\begin{array}{c}\text { Harga Penawaran } \\
\text { berdasarkan Cost } \\
\text { Significant Model } \\
(\mathbf{x 1 0 0 0} \text { Rp./m2) }\end{array}$ & $\begin{array}{c}\text { Cost Model- } \\
\text { Factor } \\
(\text { CMF })\end{array}$ \\
\hline 1 & (x1000 Rp./m2) & $3,362.37$ & 0.87 \\
2 & $3,869.84$ & $3,635.17$ & 0.90 \\
3 & $4,021.88$ & $3,545.39$ & 0.87 \\
4 & $4,059.27$ & $3,397.76$ & 0.92 \\
5 & $3,709.48$ & $4,304.09$ & 0.89 \\
6 & $4,841.41$ & $3,861.26$ & 0.89 \\
7 & $4,348.84$ & $3,731.55$ & 0.89 \\
8 & $4,171.63$ & $3,834.88$ & 0.93 \\
9 & $4,129.83$ & $2,796.13$ & 0.91 \\
10 & $3,067.05$ & $3,226.55$ & 0.91 \\
11 & $3,551.46$ & $3,233.81$ & 0.87 \\
12 & $3,704.77$ & $4,245.71$ & 0.91 \\
13 & $4,660.77$ & $4,466.00$ & 0.94 \\
14 & $4,764.97$ & $3,696.20$ & 0.92 \\
15 & $4,007.56$ & $3,720.11$ & 0.89 \\
\hline \multicolumn{5}{c}{ Rata-rata } \\
\hline
\end{tabular}

Akurasi model dapat ditentukan berdasarkan selisih antara biaya yang diperoleh menggunakan cost significant model dengan harga penawaran dibagi harga penawaran dalam prosen. Tabel 5 menunjukkan akurasi dari model.

Tabel 5 Akurasi model

\begin{tabular}{cccccc}
\hline & Harga & Harga & \multicolumn{2}{c}{ Akurasi } \\
\cline { 4 - 6 } No & $\begin{array}{c}\text { berdasarkan } \\
\text { Significant }\end{array}$ & $\begin{array}{c}\text { per m2 luas } \\
\text { lantai }\end{array}$ & Positif & Negatif \\
\cline { 5 - 6 } & $(\mathbf{x 1 0 0 0} \mathbf{~ R p} . / \mathbf{m} 2)$ & $(\mathbf{x 1 0 0 0} \mathbf{~ R p} . / \mathbf{m} 2)$ & $\mathbf{( \% )}$ & $\mathbf{( \% )}$ \\
\hline 1 & $3,731.34$ & $3,869.84$ & & $(3.58)$ \\
2 & $4,034.07$ & $4,021.88$ & 0.30 & - \\
3 & $3,934.44$ & $4,059.27$ & - & $(3.08)$
\end{tabular}




\begin{tabular}{crrrr}
4 & $3,770.61$ & $3,709.48$ & 1.65 & - \\
5 & $4,776.40$ & $4,841.41$ & - & $(1.34)$ \\
6 & $4,284.98$ & $4,348.84$ & - & $(1.47)$ \\
7 & $4,141.04$ & $4,171.63$ & - & $(0.73)$ \\
8 & $4,255.71$ & $4,129.83$ & 3.05 & - \\
9 & $3,102.97$ & $3,067.05$ & 1.17 & - \\
10 & $3,580.62$ & $3,551.46$ & 0.82 & - \\
11 & $3,588.67$ & $3,704.77$ & - & $(3.13)$ \\
12 & $4,711.62$ & $4,660.77$ & 1.09 & - \\
13 & $4,956.08$ & $4,764.97$ & 4.01 & - \\
14 & $4,101.81$ & $4,007.56$ & 2.35 & - \\
15 & $4,128.34$ & $4,174.79$ & - & $(1.11)$ \\
\hline \multicolumn{5}{c}{ Rata-rata } \\
\hline
\end{tabular}

\section{KESIMPULAN}

Berdasarkan hasil penelitian dan pembahasan yang telah dilaksanakan, dapat diperoleh simpulan sebagai berikut :

1. Faktor pekerjaan beton, pekerjaan kap, pekerjaan finishing dan pekerjaan pintu \& jendela, berpengaruh secara signifikan terhadap biaya pembangunan gedung di Kabupaten Jembrana, dimana 97,30\% biaya pembangunan gedung dipengaruhi oleh faktor-faktor tersebut, sedangkan sisanya 2,70\% dipengaruhi oleh faktor-faktor lain.

2. Model estimasi biaya pembangunan gedung di Kabupaten Jembrana dengan Cost Significant Modeladalah $: \mathrm{Y}=510,481+0,888 \mathrm{X}_{5}+1,385 \mathrm{X}_{6}+1,328 \mathrm{X}_{12}+1,726 \mathrm{X}_{8}$

$\mathrm{Y}=$ Biaya pembangunan gedung di Kabupaten Jembrana $\left(\mathrm{Rp} / \mathrm{m}^{2}\right)$.

$\mathrm{X}_{5}=$ Harga satuan pekerjaan beton $\left(\mathrm{Rp} / \mathrm{m}^{2}\right)$.

$\mathrm{X}_{6}=$ Harga satuan pekerjaan $\mathrm{kap}\left(\mathrm{Rp} / \mathrm{m}^{2}\right)$.

$\mathrm{X}_{12}=$ Harga satuan pekerjaan finishing $\left(\mathrm{Rp} / \mathrm{m}^{2}\right)$.

$\mathrm{X}_{8}=$ Harga satuan pekerjaan pintu \& jendela $\left(\mathrm{Rp} / \mathrm{m}^{2}\right)$.

3. Akurasi model estimasi biaya pemeliharaan berkala jalan dengan metode Cost Significant Modeladalah berkisar antara $0,30 \%$ sampai dengan $4,01 \%$, dengan rata-rata $1,81 \%$ untuk yang bernilai positif dan berkisar antara $0,73 \%$ sampai dengan $-3,58 \%$ dengan rata-rata $-2,06 \%$ untuk yang bernilai negatif.

\section{REKOMENDASI}

1. Untuk memperoleh gambaran awal biaya pembangunan gedung dengan cepat, Cost Significant Modelsangat tepat digunakan, sehingga memudahkan di dalam penyusunan anggaran.

2. Untuk memperoleh model yang lebih detail, perlu mengembangkan lebih rinci komponen-komponen dari pekerjaan beton, pekerjaan kap, pekerjaan finishing dan pekerjaan pintu \& jendela, sehingga lebih memudahkan dan lebih praktis dalam melakukan estimasi.

\section{DAFTAR PUSTAKA}

[1] Soeharto, Imam. 1995. Manajemen Proyek dari Konseptual sampai Operasional. Jakarta: Erlangga.

[2] Ervianto, Wulfram I. 2002. Teori-Aplikasi Manajemen Proyek Konstruksi. Yogyakarta: Andi Offset.

[3] Dipohusodo, Istimawan. 1996. Manajemen Proyek dan Konstruksi Jilid 2. Yogyakarta: Kanisius.

[4] Poh, Paul SH dan Horner R Malcolm W .1995. "Cost-Significant Modelling-Its Potential For Use In South-East Asia" : Paper in Engineering, Construction and Architectural Management. 85

[5] Kushartini, M G Wara. 2002. Pengembangan Cost Significant Modelling untuk Estimasi Biaya Proyek Pengairan (tesis).Yogyakarta: Universitas Atma Jaya.

[6] Budi, Triton Prawira. 2006. SPSS 13.0 Terapan: Riset Statistik Parametrik. Yogyakarta : Andi.

[7] Giatman, M. 2007. Ekonomi Teknik. Jakarta : Raja Grafindo Persada 